For further information on submitting an abstract for consideration, please visit www.aats.org or contact:

American Association for Thoracic Surgery

500 Cummings Center

Suite 4550, Beverly, MA, USA 01915

Telephone: +1 (978) 927-8330

Fax: + 1 (978) 524-0498

E-mail: meetings@aats.org

\section{AATS Meetings and Sponsored Events www.aats.org}

October 7-8, 2011

3rd International Biennial Minimally Invasive Thoracic Surgery Summit*

The Joseph B. Martin Conference Center at Harvard Medical School

Boston, Massachusetts
October 13-15, 2011

2011 Heart Valve Summit: Medical, Surgical, and Interventional Decision Making

JW Marriott Chicago

Chicago, Illinois

October 20-21, 2011

7th Triennial Brigham Cardiac Valve Symposium*

Fairmont Copley Plaza Hotel

Boston, Massachusetts

November 7-9, 2011

Surgical Innovation Summit: Cutting-Edge Therapies for Cardiovascular and Valve Disease*

Moscone Convention Center

San Francisco, California

*Cosponsored by AATS.

\section{The Western Thoracic Surgical Association}

\section{Applications for Membership}

The WTSA Application for Membership is now online and must be submitted electronically. A candidate's application must include the following uploads: A photo, a complete curriculum vitae with bibliography, and the three most significant articles that s/he personally wrote. The candidate's electronic membership application must be completed and submitted online by March 1, 2012, and all support letters uploaded by that candidate's sponsors by March 31, 2012, in order for the candidate to be considered for election to membership at the 2012 Annual Meeting. Visit the WTSA Web site at www.westernthoracic.org to read membership eligibility requirements and to initiate an online application.

\section{WTSA 38th Annual Meeting}

Save the Date!

June 27-30, 2012

The Grand Wailea

Maui, Hawaii

\section{The American Board of Thoracic Surgery}

\section{Notices}

The part I (written) examination was held on December 3. It is planned that this examination will be given at multiple sites throughout the United States using an electronic format. The closing date for registration is August 1 each year. Those wishing to be considered for examination must apply online at www.abts.org.

To be admissible for the Part II (oral) examination, a candidate must have successfully completed the Part I (written) examination.

A candidate applying for admission to the certifying examination must fulfill all the requirements of the Board in force at the time the application is received. Please address all communications to the American Board of Thoracic Surgery, 633 North St Clair Street, Suite 2320, Chicago, IL 60611 (telephone: 312-202-5900).

\section{Requirements for Maintenance of Certification}

Diplomates of the American Board of Thoracic Surgery (ABTS) who plan to participate in the Maintenance of Certification (MOC) process must hold an unrestricted medical license in the locale of their practice and privileges in a hospital accredited by the JCAHO (or other organization recognized by the ABTS). In addition, a valid ABTS certificate is an absolute requirement for entrance into the Maintenance of Certification process. If your certificate has expired, the only pathway for renewal of a certificate is to take and pass the Part I (written) and the Part II (oral) certifying examinations. The names of individuals who have not maintained their certificate will no longer be published in the American Board of Medical Specialties Directories. Diplomates' names will be published upon successful completion of the Maintenance of Certification process.

The CME requirements are 30 Category I credits earned during each year prior to application. At least half of these CME hours need to be in the broad area of thoracic surgery. 